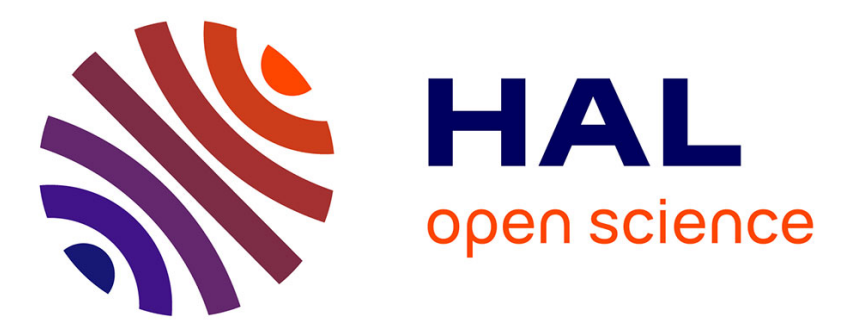

\title{
Comment on "The ultimate arc: Differential displacements, oroclinal bending, and vertical axis rotation in the External Betic-Rif arc" by J.P. Platt et al.
}

A. Michard, Dominique Frizon de Lamotte, A. Chalouan

\section{To cite this version:}

A. Michard, Dominique Frizon de Lamotte, A. Chalouan. Comment on "The ultimate arc: Differential displacements, oroclinal bending, and vertical axis rotation in the External Betic-Rif arc" by J.P. Platt et al.. Tectonics, 2005, 24, pp.1-3. 10.1029/2003TC001603 . hal-00022423

\section{HAL Id: hal-00022423 \\ https://hal.science/hal-00022423}

Submitted on 19 Feb 2021

HAL is a multi-disciplinary open access archive for the deposit and dissemination of scientific research documents, whether they are published or not. The documents may come from teaching and research institutions in France or abroad, or from public or private research centers.
L'archive ouverte pluridisciplinaire HAL, est destinée au dépôt et à la diffusion de documents scientifiques de niveau recherche, publiés ou non, émanant des établissements d'enseignement et de recherche français ou étrangers, des laboratoires publics ou privés. 


\title{
Comment on "The ultimate arc: Differential displacements, oroclinal bending, and vertical axis rotation in the External Betic-Rif arc" by J. P. Platt et al.
}

\author{
A. Michard \\ Laboratoire de Géologie, Ecole Normale Supérieure, Paris, France \\ D. Frizon de Lamotte \\ Département des Sciences de la Terre et de l'Environnement, Université de Cergy-Pontoise, Cergy, France
}

\begin{abstract}
A. Chalouan
Département de Géologie, Faculté des Sciences, Université Mohamed V, Rabat, Maroc
\end{abstract}

Received 28 November 2003; revised 16 July 2004; accepted 27 September 2004; published 5 February 2005.

Citation: Michard, A., D. Frizon de Lamotte, and A. Chalouan (2005), Comment on "The ultimate arc: Differential displacements, oroclinal bending, and vertical axis rotation in the External Betic-Rif arc" by J. P. Platt et al., Tectonics, 24, TC1005, doi:10.1029/2003TC001603.

[1] Platt et al. [2003a] have made a major contribution to our knowledge of the Gibraltar arc by documenting the kinematics of the Betic-Rif External zones through structural and palaeomagnetic measurements. They suggest that the "External Betic-Rif arc" is a thin-skinned fold-andthrust belt formed in Miocene time as a result of two causes, i.e., first, the westward component of motion of the "indenting Alboran Domain" (Betic-Rif Internal zones) relative to the convergent Iberian and African plates; and second, the extensional collapse of the Alboran Domain.

[2] The concept of an "indenting Alboran Domain" goes back to the work of Andrieux et al. [1971], who referred to an "Alboran microplate." We argue hereafter that the "Alboran Domain" did not act as an indenter, and that both its collapse and the external Betic and Rif fold belts are consequences of a slab retreat process. We also emphasize that defining the Betic and Rif external fold-and-thrust belts as a single, thin-skinned arc is misleading.

[3] The crucial role of the late orogenic collapse in the building of the Betic-Rif chain goes back to the work of Platt and Vissers [1989], who assumed that it was an intracontinental collisional orogen, formed at the expense of the neighboring Iberian and African margins, without any oceanic domain nor exotic terrane in between. However, relics of lost oceans do occur (1) along the African margin, i.e., the Beni Malek serpentinites and basalts at the very edge of the margin [Michard et al., 1992] and the spilites and radiolarites at the bottom of the exotic Flyschs [Durand-Delga et al., 2000], which altogether document a former Maghrebian ocean, and (2) on top of the NevadoFilabrides units of central eastern Betics, i.e., the metaser-

Copyright 2005 by the American Geophysical Union. 0278-7407/05/2003TC001603 pentinites and metabasalts of the Mulhacen complex, which document a former Betic ocean [Puga et al., 1999, 2002a, 2002b]. The occurrence of former oceanic domains makes necessary to consider subduction processes there. Some authors even assume that two subduction zones operated, first the SE dipping Alpine-Betic subduction, then the NW dipping Apenninic-Maghrebian subduction [Rehault et al., 1984; Torres-Roldan et al., 1986; Andrieux et al., 1989; Guerrera et al., 1993; Doglioni et al., 1998, 1999; Frizon de Lamotte et al., 2000; Chalouan et al., 2001; Michard et al., 2002; Chalouan and Michard, 2004]. Consistently, east dipping active subduction beneath the Gibraltar arc is currently evidenced [Morales et al., 1999; Gutscher et al., 2002].

[4] Platt et al. [2003a] accept the concept of an easterly, allochthonous "Alboran Domain." In fact, the latter includes two different tectonic systems, the Nevado-Filabrides (NF) at the bottom, and the "Alboran Terrane" on top, which in turn consists of the metamorphic Alpujarrides-Sebtides (AS) overlain by the Malaguide-Ghomarides and Dorsale Calcaire units [Chalouan et al., 2001; Michard et al., 2002, and references therein]. The NF consists of the HT-LP Veleta schists overlain by the HP-LT Mulhacen Complex, which has the characters of a subduction tectonic complex [Puga et al., 1999, 2002a, 2002b]. Only the Alboran Terrane does represent an exotic domain of easterly origin [Bouillin et al., 1986; Michard et al., 1991, 2002]. As the Alboran Terrane formed at the onset of Neogene times an orogenic prism made of young, ductile metamorphic units, it can hardly be regarded as an "indenter," which would be the initial cause of the "External Arc" building. We rather suggest considering that the Alboran Terrane operated as a backstop related to the subduction of the Maghrebian Tethys (see section 6).

[5] Platt et al. [2003a] argue that "the present dramatic geometry of the arc is a result of extensional collapse of the Alboran Domain during the Miocene." They agree that the subduction rollback hypothesis [Frizon de Lamotte et al., 1991; Lonergan and White, 1997] could be "reasonably" proposed, but prefer the collapse mechanism that they also consider as the cause of the opening of the Algerian basin 
Tyrrhenian and Ligurian seas. In another, almost coeval paper, Platt et al. [2003b] present the convective removal of subcontinental lithosphere as the only mechanism which may completely explain the late orogenic extension in the Alboran area. Likewise, Platt et al. [2003c] suggest a gravitational emplacement of the Ronda peridotites on top of a deeper Alpujarride crustal unit, while the compressional emplacement of these mantle slices within the Alpujarride nappe stack has been demonstrated by Balanyá et al. [1997, 1998].

[6] At the scale of the whole western Mediterranean, after the pioneering work of Rehault et al. [1984], the occurrence of a north dipping subduction zone from Oligocene up to Present was demonstrated repeatedly based on structural, sedimentary, magmatic, paleomagnetic, and/or tomographic arguments [Frizon de Lamotte et al., 1991; Royden, 1993; Lonergan and White, 1997; Faccenna et al., 1997; Gueguen et al., 1997; Boccaletti et al., 1997; van der Meulen et al., 1999; Maury et al., 2000; Frizon de Lamotte et al., 2000; Crespo-Blanc and Campos, 2001; Michard et al., 2002; Jolivet et al., 2003; Faccenna et al., 2004]. Doglioni et al. [1998, 1999] and Michard et al. [2002] emphasized the continuity of this subduction zone with the backthrust zone of Western Alps. HP-LT metamorphism constitutes the petrological record of this subduction zone in Tuscany and Calabria [Brunet et al., 2000; Rossetti et al., 2001], and possibly in the Rif and Betics [Chalouan and Michard, 2004].

[7] Iberia and Africa are two distinct plates. The southern Iberian margin and the North-African margin show contrasting sedimentary histories. Then the Betic-Rif external zones do not really form an "arc." The arcuated internal zones have two distinct foreland belts, separated by a major plate boundary, i.e., the western prolongation of the AzoresGibraltar transform fault.

[8] The external Rif cannot be defined as a thin-skinnned fold-and-thrust belt [Platt et al., 2003a]. Crustal rocks crop out in the eastern external Rif, i.e., the Beni Malek serpentinites [Michard et al., 1992; Elazzab et al., 1997] and the
Paleozoic crystalline rocks of the Senhadja unit [Andrieux, 1971], showing that the basement is involved in the compressional structures there. Only the more external part of the belt (Prerif) is a thin-skinned fold-and-thrust belt [Zizi, 1996, 2002]. Frizon de Lamotte et al. [1991], Favre [1995], and Chalouan et al. [2001] presented cross sections of the External Rif consistent with these data. Accordingly, the shortening estimates proposed by Platt et al. [2003a] are exaggerated. In addition, gravity modeling by Favre [1995] suggests that the African Moho deepens down to $\sim 35 \mathrm{~km}$ depth beneath the northernmost external units (Intrarif), and then that the top of the thinned margin crust deepens at $\sim 20 \mathrm{~km}$ depth there, more than twice the depth indicated by Platt et al. [2003a] in their Figure 14.

[9] The presentation of the External Rif as the result of "the extensional collapse of the Alboran domain during the Miocene" is controversial. The existence of a pre-late Oligocene (likely late Eocene) compressive event in the Intra- and Mesorif has been emphasized by Andrieux [1971], Monié et al. [1984], Morley [1992], Favre [1995], and Chalouan et al. [2001]. This early inversion occurring along the foot of the African margin cannot be explained by the alleged collapse. More generally, the overall Miocene deformation suggests an accretionary prism related to the westward retreat of the Maghrebian slab (see Flinch [1996] or Zizi [2002]).

[10] As for the Ronda section of the external Betic domain presented by Platt et al. [2003a] in their Figure 11, it does not fit the actual structure of the area as (1) the allochthonous Flysch units are not overlain by the Internal Subbetic units (except quite locally, because of their common, late deformation), but are thrust over the latter [Crespo-Blanc and Campos, 2001; Luján et al., 2003, and references therein]; (2) seismic lines at the southern boundary of the Guadalquivir basin show that the top of the Hercynian basement deepens much more quickly to the SE beneath the Prebetic-Subbetic domain, up to depths in excess of $10 \mathrm{~km}$ below the Internal Zones [Berástegui et al., 1998, and references therein].

\section{References}

Andrieux, J. (1971), La structure du Rif central: Etudes des relations entre la tectonique de compression et les nappes de glissement dans un tronçon de la chaîne alpine, Notes Mem. Serv. Geol., $235,155 \mathrm{pp}$

Andrieux, J., J. M. Fontboté, and M. Mattauer (1971), Sur un modele explicatif de l'Arc de Gibraltar, Earth Planet. Sci. Lett., 12, 191-198.

Andrieux, J., D. Frizon de Lamotte, and J. Braud (1989), A structural scheme for the western Mediterranean area in Jurassic and Early Cretaceous times, Geodin. Acta, 3, 5-15.

Balanyá, J. C., V. García-Dueñas, J. M. Azañón, and M. Sánchez-Gómez (1997), Alternating contractional and extensional events in the Alpujarride nappes of the Alboran Domain (Betics, Gibraltar Arc), Tectonics, 16, 226-238.

Balanyá, J. C., V. García-Dueñas, J. M. Azañón, and M. Sánchez-Gómez (1998), Reply to comment by J. P. Platt on "Alternating contractional and extensional events in the Alpujarride nappes of the Al- boran Domain (Betics, Gibraltar Arc)", Tectonics, 17, 977-981

Berástegui, X., C. J. Banks, C. Puig, C. Taberner, D. Waltham, and M. Fernàndez (1998), Lateral diapiric emplacement of Triassic evaporites at the southern margin of the Guadalquivir Basin, Spain, in Cenozoic Foreland Basins of Western Europe, edited by A. Mascle et al., Geol. Soc. Spec. Publ., 134, 49-68.

Boccaletti, M., G. Gianelli, and F. Sani (1997), Tectonic regime, granite emplacement and crustal structure in the inner zone of the Northern Apennines (Tuscany, Italy): A new hypothesis, Tectonophysics, 270, 127-143.

Bouillin, J. P., M. Durand-Delga, and P. Olivier (1986), Betic-Rifian and Tyrrhenian Arcs: Distinctive features, genesis, and development stages, in The Origin of Arcs, edited by F. C. Wezel, pp. 281-304, Elsevier Sci., New York.

Brunet, C., P. Monié, L. Jolivet, and J. P. Cadet (2000), Migration of compression and extension in the Tyr- rhenian Sea, Insights from ${ }^{40} \mathrm{Ar} /{ }^{39} \mathrm{Ar}$ ages on micas along a transect from Corsica to Tuscany, Tectonophysics, 321, 127-155.

Chalouan, A., and A. Michard (2004), The Alpine Rif belt (Morocco): A case of mountain building in a subduction-subduction-transform fault triple junction, Pure Appl. Geophys., 161, $489-519$

Chalouan, A., A. Michard, H. Feinberg, R. Montigny, and O. Saddiqi (2001), The Rif mountain building (Morocco): A new tectonic scenario, Bull. Soc. Geol. Fr., 172, 603-616.

Crespo-Blanc, A., and J. Campos (2001), Structure and kinematics of the South Iberian paleomargin and its relationship with the Flysch Trough units: Extensional tectonics within the Gibraltar Arc fold-andthrust belt (western Betics), J. Struct. Geol., 23, $1615-1630$.

Doglioni, C., F. Mongelli, and G. Pialli (1998), Boudinage of the Alpine belt in the Apenninic back-arc, Mem. Soc. Geol. Ital., 52, 457-468. 
Doglioni, C., M. Fernandez, E. Gueguen, and F. Sabat (1999), On the interference between the early Apennines-Maghrebides back-arc extension and the Alps-Betics orogen in the Neogene geodynamics of the western Mediterranean, Bull. Soc. Geol. Ital., 118, 75-89.

Durand-Delga, M., P. Rossi, P. Olivier, and D. Puglisi (2000), Situation structurale et nature ophiolitique de roches basiques jurassiques associées aux flyschs maghrébins du Rif (Maroc) et de Sicile (Italie), C. R. Acad. Sci., 331, 29-38.

Elazzab, D., A. Galdeano, H. Feinberg, and A. Michard (1997), Prolongement en profondeur d'une écaille ultrabasique allochtone: Traitement des données aéromagnétiques et modélisation $3 \mathrm{D}$ des péridotites des Beni Malek (Rif, Maroc), Bull. Soc. Geol. Fr., $168,667-683$

Faccenna, C., M. Mattei, R. Funiciello, and L. Jolivet (1997), Styles of back-arc extension in the central Mediterranean, Terra Nova, 9, 126-130.

Faccenna, C., C. Piromallo, A. Crespo-Blanc, L. Jolivet, and F. Rossetti (2004), Lateral slab deformation and the origin of the western Mediterranean arcs, Tectonics, 23, TC1012, doi:10.1029/2002TC001488.

Favre, P. (1995), Analyse quantitative du rifting et de la relaxation thermique de la partie occidentale de la marge transformante nord-africaine: Le Rif externe (Maroc), Comparaison avec la structure actuelle de la chaîne, Geodin. Acta, 8, 59-81.

Flinch, F. J. (1996), Accretion and extensional collapse of the external Western Rif (northern Morocco), in Peri-Tethys Memoir 2: Structure and Prospects of Alpine Basins and Forelands, edited by P. A. Ziegler and F. Horvath, Mem. Mus. Natl. Hist. Nat., 170, $61-85$.

Frizon de Lamotte, D., J. Andrieux, and J. C. Guezou (1991), Cinématique des chevauchements néogènes dans l'Arc bético-rifain: Discussion sur les modèles géodynamiques, Bull. Soc. Geol. Fr., 169, 611-626.

Frizon de Lamotte, D., B. Saint Bezar, R. Bracène, and E. Mercier (2000), The two main steps of the Atlas building and geodynamics of the western Mediterranean, Tectonics, 19, 740-761.

Gueguen, E., C. Doglioni, and M. Fernandez (1997), Lithospheric boudinage in the western Mediterranean backarc basins, Terra Nova, 9, 184-187.

Guerrera, F., A. Martin-Algarra, and V. Perrone (1993), Late Oligocene-Miocene syn-/-late orogenic successions in western and central Mediterranean chains from the Betic Cordillera to the southern Apennines, Terra Nova, 5, 525-554.

Gutscher, M. A., J. Malod, J. P. Rehault, I. Contrucci, F. Klingelhoefer, L. Mendes-Victor, and W. Spakman (2002), Evidence for active subduction beneath Gibraltar, Geology, 30, 1071-1074.

Jolivet, L., C. Faccenna, B. Goffé, E. Burov, and P. Agard (2003), Subduction tectonics and exhumation of high-pressure metamorphic rocks in the Mediterranean orogens, Am. J. Sci., 303, 353-409.

Lonergan, L., and N. White (1997), Origin of the BeticRif mountain belt, Tectonics, 16, 504-522.
Luján, M., F. Storti, J. C. Balanyá, A. Crespo-Blanc, and F. Rossetti (2003), Role of décollement material with different rheological properties in the structure of the Aljibe thrust imbricate (Flysch Trough, Gibraltar Arc): An analogue modelling approach, J. Struct. Geol., 25, 867-881.

Maury, R. C., et al. (2000), Post-collisional Neogene magmatism of the Mediterranean Maghreb margin: A consequence of slab breakoff, C. R. Acad. Sci., $331,159-173$.

Michard, A., B. Goffé, A. Chalouan, and O. Saddiqi (1991), Les corrélations entre les Chaînes bético-rifaines et les Alpes et leurs conséquences, Bull. Soc. Geol. Fr., 162, 1151-1160.

Michard, A., H. Feinberg, D. Elazzab, M. Bouybaouene, and O. Saddiqi (1992), A serpentinite ridge in a collisional paleomargin setting: the Beni Malek massif, External Rif, Morocco, Earth Planet. Sci. Lett., 113, 435-442.

Michard, A., A. Chalouan, H. Feinberg, B. Goffé, and R. Montigny (2002), How does the Alpine belt end between Spain and Morocco?, Bull. Soc. Geol. Fr. 173, 3-15.

Monié, P., D. Frizon de Lamotte, and M. Leikine (1984), Etude géologique préliminaire par la méthode ${ }^{39} \mathrm{Ar} /{ }^{40} \mathrm{Ar}$ du métamorphisme alpin dans le Rif externe (Maroc): Précisions sur le calendrier tectonique tertiaire, Rev. Geol. Dyn. Geogr. Phys., 25, 307-317.

Morales, J., I. Serrano, A. Jabaloy, J. Galindo-Zaldivar, D. Zhao, F. Torcal, F. Vidal, and F. González-Lodeiro (1999), Active continental subduction beneath the Betic Cordillera and the Alboran Sea, Geology, 27, $735-738$.

Morley, C. K. (1992), Notes on Neogene basin history of the western Alboran Sea and its implications for the tectonic evolution of the Rif-Betic orogenic belt, J. Afr. Earth Sci., 14, 57-65.

Platt, J. P., and R. L. M. Vissers (1989), Extensional collapse of thickened continental lithosphere: A working hypothesis for the Alboran Sea and Gibraltar Arc, Geology, 17, 540-543.

Platt, J. P., S. Allerton, A. Kirker, C. Mandeville, A. Mayfield, E. S. Platzman, and A. Rimi (2003a), The ultimate arc: Differential displacement, oroclina bending, and vertical axis rotation in the External Betic-Rif arc, Tectonics, 22(3), 1017, doi:10.1029/ 2001TC001321

Platt, J. P., M. J. Whitehouse, S. P. Kelley, A. Carter, and L. Hollick (2003b), Simultaneous extensiona exhumation across the Alboran Basin: Implications for the causes of late orogenic extension, Geology, $31,251-254$

Platt, J. P., T. W. Argles, A. Carter, S. P. Kelley, M. J. Whitehouse, S. P. Kelley, and L. Lonergan (2003c), Exhumation of the Ronda peridotite and its crustal envelope: Constraints from thermal modelling of a P-T-time array, J. Geol. Soc. London, 160, $655-$ 676.

Puga, E., J. M. Nieto, A. Díaz de Federico, J. L. Bodinier, and L. Morten (1999), Petrology and metamorphic evolution of ultramafic rocks and dolerite dykes of the Betic Ophiolitic Association (Mulhacen Complex, SE Spain): Evidence of eo-Alpine subduction following an ocean-floor metasomatic process, Lithos, 49, 23-56.

Puga, E., A. Díaz de Federico, and J. M. Nieto (2002a), Tectonostratigraphic subdivision and petrological characterisation of the deepest complexes of the Betic zone: A review, Geodin. Acta, 15, $23-43$.

Puga, E., M. D. Ruiz Cruz, and A. Díaz de Federico (2002b), Polymetamorphic amphibole veins in metabasalts from the Betic ophiolitic association at Cóbdar, southern Spain: Relics of ocean-floor metamorphism preserved through the Alpine orogeny, Can. Mineral., 40, 67-83.

Rehault, J. P., G. Boillot, and A. Mauffret (1984), The western Mediterranean basin geological evolution, Mar. Geol., 55, 447-477.

Rossetti, F., C. Faccenna, B. Goffé, P. Monié, A. Argentieri, R. Funiciello, and M. Mattei (2001), Alpine structural and metamorphic signature of the Sila Piccola Massif nappe stack (Calabria, Italy): Insights for the tectonic evolution of the Calabrian Arc, Tectonics, 20, 112-133.

Royden, L. H. (1993), Evolution of retreating subduction boundaries formed during continental collision, Tectonics, 12, 629-638.

Torres-Roldan, R. L., G. Poli, and A. Pesserillo (1986), An early Miocene arc-tholeitic magmatic dike event from the Alboran Sea: Evidence for precollisional subduction and back-arc crustal extension in the westernmost Mediterranean, Geol. Rundsch., 75, 219-234.

van der Meulen, M. J., T. J. Kouwenhoven, G. J. Zwaan, J. E. van der Meulenkamp, and M. J. R. Wortel (1999), Late Miocene uplift in the Romagnan Apennines and the detachment of subducted lithosphere, Tectonophysics, 315, 319335.

Zizi, M. (1996), Triassic-Jurassic extension and Alpine inversion in Northern Morocco, in Peri-Tethys Memoir 2: Structure and Prospects of Alpine Basins and Forelands, edited by P. Ziegler and F. Horvath, Mem. Mus. Natl. Hist. Nat., 170, $87-101$.

Zizi, M. (2002), Triassic-Jurassic extensional systems and their Neogene reactivation in northern Morocco, the Rides prérifaines and Guercif basin, Notes Mem. Serv. Geol., 416, 138 pp.

A. Chalouan, Département de Géologie, Faculté des Sciences, B.P.1014, Rabat Agdal, Maroc.

D. Frizon de Lamotte, Département des Sciences de la Terre et de l'Environnement (CNRS UMR 7072), Université de Cergy-Pontoise, F-95011 Cergy-Pontoise Cedex, France.

A. Michard, Laboratoire de Géologie, Ecole Normale Supérieure, 24, rue Lhomond, F-75231 Paris Cedex 05, France. (michard@geologie.ens.fr) 